\title{
Density as Estimator of Strength in Compression Parallel to the Grain in Wood
}

\author{
Tiago Hendrigo de Almeida ${ }^{1}$, Diego Henrique de Almeida ${ }^{2}$, André Luis Christoforo ${ }^{3, *}$, Eduardo Chahud ${ }^{4}$, \\ Luiz Antônio Melgaço Nunes Branco ${ }^{5}$, Francisco Antonio Rocco Lahr ${ }^{6}$
}

\author{
${ }^{1}$ Department of Materials (SMM), São Paulo University (EESC/USP), São Carlos, Brazil \\ ${ }^{2}$ Department of Engineering, Pitágoras College, Poços de Caldas, Brazil \\ ${ }^{3}$ Centre for Innovation and Technology in Composites - CITeC, Department of Civil Engineering (DECiv), \\ Federal University of São Carlos, São Carlos, Brazil \\ ${ }^{4}$ Department of Civil Engineering, Federal University of Minas Gerais (UFMG), Belo Horizonte, Brazil \\ ${ }^{5}$ Faculty of Engineering and Architecture, FUMEC University, Belo Horizonte, Brazil \\ ${ }^{6}$ Department of Structural Engineering (SET), São Paulo University (EESC/USP), São Carlos, Brazil
}

\begin{abstract}
Wood is a renewable material, presenting wide use in building construction. For its better employability, it is necessary to perform physical and mechanical characterization of the several species available for application. In this respect, Brazilian Code ABNT NBR 7190:1997 - Timber Structures Design, in its Annex B, prescribes the proper tests and adds some relations between properties and strength classes for coniferous and dicotyledonous. The strength classes are function of characteristics values of strength in compression parallel to grain $\left(f_{c 0}\right)$. However, density is a more easy-determination property and the cited Code presents the mean value of density for each strength class. Therefore, this research aimed to evaluate the possibility of inferring $f_{c 0}$ based on density obtained on tests of three Brazilian tropical wood species: Canafístula (Cassia ferruginea); Angelim araroba (Vataireopsis araroba) e Castelo (Gossypiospermum sp.). Statistical procedures shown it is possible to conclude that, in some cases, density is not a good estimator of $f_{c 0}$.
\end{abstract}

Keywords Bootstrap, Apparent density, Wood, Strength

\section{Introduction}

Wood is a renewable material, presenting wide use in building construction due its interesting physical and mechanical properties. Additionally, wood presents a high convenient rate between strength and density, which makes it an excellent alternative for structural purposes. [1-4].

In Brazil, the design of timber structures, as well as the characterization of this material, follows assumptions and calculation methods of the Annex B, Brazilian Code ABNT NBR 7190: 1997 (Design of timber structures). Among the mechanical properties, strength in compression parallel to grain $\left(f_{c 0}\right)$ is one of the most important, because with this parameter wood species are categorized into strength classes, to two specific groups: coniferous (softwoods), for which three classes $(\mathrm{C} 20, \mathrm{C} 25, \mathrm{C} 30)$ are established; and dicotyledonous (hardwoods), wherein materials are divided into four classes (D20, D30, D40, D60). [5-7].

The normative document cited also proposes relationships between several mechanical properties and strength in

* Corresponding author:

christoforoal@yahoo.com.br (André Luis Christoforo)

Published online at http://journal.sapub.org/ijme

Copyright (C) 2016 Scientific \& Academic Publishing. All Rights Reserved compression parallel to grain, aiming to estimate wood parameters, thus facilitating characterization procedures [8-11].

Among the physical properties of wood, density is the most easily determinable, being the ratio between mass and volume of the sample, in a given moisture content. It fits to emphasize the possibility of estimating strength and stiffness values of timber based on its density, an interesting subject that has been focused by some researchers in this knowledge area [12-14].

In their studies, Dias and Rocco Lahr [5] concluded that it is possible to admit dependency between density (12\%) and strength in compression parallel grain, described in equation

$$
f_{c 0}=0.0714 \rho 12^{1.006}
$$

with $\mathrm{R}^{2}=0.77$. This result was obtained by performing tests on forty Brazilian tropical wood species. Therefore, the equation presented by authors shown fairly representative.

Sales and Rocco Lahr [15], working with thirty dicotyledonous wood species, held their classification in strength classes, for improvement the Brazilian Code. In this paper, the researchers predetermined mean densities for each strength class, which suggests that it is possible to admit a direct dependence between density ( $12 \%$ moisture content) and strength in to compression parallel to grain.

On the other hand, expressive differences in anatomical 
characteristics are a well-known aspect in wood studies. These differences will influence the mechanical strength of the material, depending on the direction in which the pieces are stressed $[16,17]$. Using mean values of density $(15 \%$ moisture content) and strength in compression parallel to grain of twenty species chosen from IPT Bulletin 31 [18], the graphic (Figure 1) summarizes results of the species: Jatobá (Hymenaea stilbocarpa), (Hymenaea coubaril); Cabreúva (Myroxylon balsamum); Itaúba (Mezilaurus Itauba); Faveiro (Pterodon pubescens); Sucupira (Bowdichia virgilioides); Guarucaia (Pelthoforum vogelianum); Garapa (Apuleia leiocarpa); Copaíba (Copaifera langsdorffii); Jatobá Amarelo (Hymenaea sp.); Louro (Cordia sp.). It is perceived, by the dispersion of the points, as well as by $\mathrm{R}^{2}=0.25$, that there is a weak interspecific correlation between the variables.

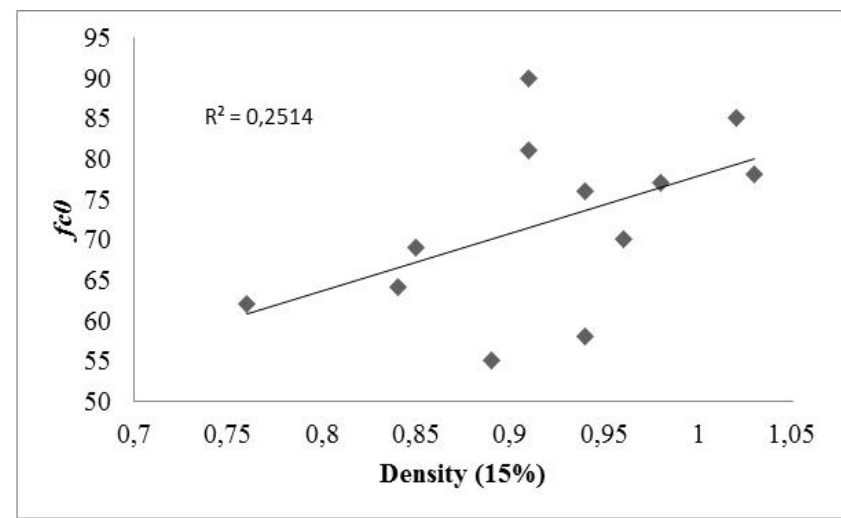

Figure 1. Strength in compression parallel to grain (MPa) as function of density, moisture content $15 \%\left(\mathrm{~g} / \mathrm{cm}^{3}\right)$. Adapted from [18]

This study aimed to investigate, with the fundaments of Brazilian Code NBR 7190: 1997 [6] and the analysis of variance of regression models, the possibility of estimating strength in compression parallel to grain based on values of the density at $12 \%$ moisture content $\left(\rho_{12}\right)$, considering tropical wood species.

\section{Material and Methods}

Density $\left(\rho_{12}\right)$ and strength in compression parallel to grain $\left(f_{c 0}\right)$ of the three wood species considered: Canafístula (Cassia ferruginea); Angelim araroba (Vataireopsis araroba) e Castelo (Gossypiospermum sp.), inserted in three of the four strength classes of dicotyledonous woods, were determined obeying the requirements of ABNT NBR 7190:1997, Annex B. Twelve specimens were obtained for each species and each property, one by piece sampled, totaling seventy two determinations. Figure 2 shows images of wood species here studied.

After obtaining the values of strength in compression parallel to grain, their characteristic strength $\left(f_{c 0, k}\right)$ were calculated using equation 2 , thus making it possible to categorize the species in strength classes.

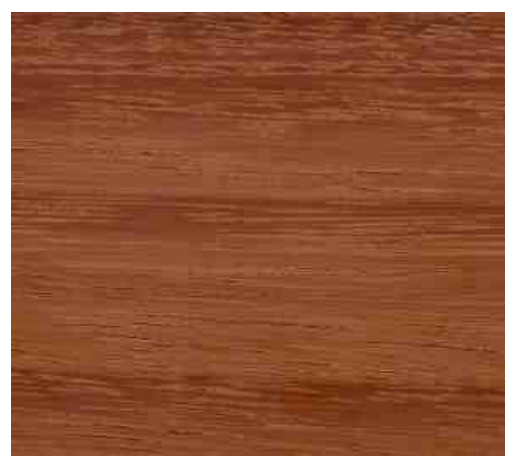

(a) Source: www.mabmadeiras.com.br

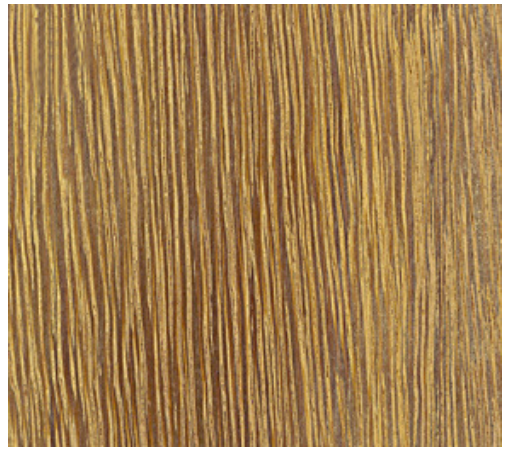

(b) Source: http://www.ipt.br/ipt/areas/ctfloresta/

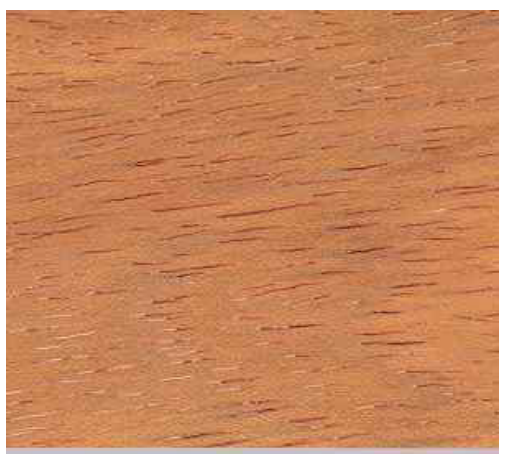

(c) source: www.mabmadeiras.com.br

Figure 2. Wood species - Canafístula (a), Angelim Araroba (b) e Castelo (c)

$$
f_{c 0, k}=\left(2 \cdot \frac{f_{1}+f_{2}+f_{3}+\ldots+f_{(n / 2)-1}}{(n / 2)-1}-f_{n / 2}\right) \cdot 1.10
$$

In Equation 2, the strength values should be placed in ascending order $\left(f_{1} \leq f_{2} \leq f_{3} \ldots \leq f_{n}\right)$, disregarding the greater if the number of specimens is odd, not taking for $f_{C O, k}$ value lower than $\mathrm{f}_{1}$ and less than 0.70 or the mean strength value, as imposed by NBR 7190: 1997 [6].

Regression models used to estimate strength in compression parallel to grain by density are shown in Equations 3 to 6 , being "a", "b" and "c" parameters of the functions set by the least squares method.

$$
\begin{aligned}
& f_{c 0}=a+b \cdot \rho_{12} \\
& f_{c 0}=a \cdot e^{b \cdot \rho_{12}} \quad[\operatorname{Lin}] \\
&
\end{aligned}
$$




$$
\begin{gathered}
f_{c 0}=a+b \cdot \operatorname{Ln}\left(\rho_{12}\right) \quad[\log ] \\
f_{c 0}=a \cdot \rho_{12}{ }^{b} \quad[\mathrm{Geo}]
\end{gathered}
$$

Relations tested in this study were performed by analysis and variance (ANOVA) of the regression models, considering level of significance $(\alpha) 5 \%$. It was adopted the non-representativity of the models tested as null hypothesis $\left(H_{0}: \beta=0\right)$ and the representativity as alternative hypothesis $\left(H_{1}: \beta \neq 0\right)$. P-value higher than the level of significance implies accepting $H_{0}$ (the model tested is not representative $\rho_{12}$ variations are not able to explain variations in $f_{c 0}$ ), refuting it otherwise (the tested model is representative).

Besides the use of ANOVA, which allows to accept or not the representativity of the tested models, values of the coefficient of determination $\left[\mathrm{R}^{2}\right]$ were obtained in order to assess the ability of variations of independent variable $\rho_{12}$ in explaining predictive variable $f_{c 0}$. This allows selecting, among the models considered significant, the best fit for tested relations.

The efficiency of regression models was tested considering wood species separately and then all together in order to evaluate accuracy of the adjustments for each species and for all of them (representation of dicotyledonous strength classes).

Being linear the best fit (among those tested) obtained by considering all species together, Bootstrap test (re-sampling technique) with $95 \%$ reliability was used to assess the confidence interval (CI) of Pearson correlation coefficient (r) for 80,000 simulations, allowing estimate the magnitude of " $r$ " values at $5 \%$ significance level.

\section{Results and Discussion}

Table 1 shows mean values $(\bar{x})$, coefficients of variation $(C v)$, smaller (Min) and highest (Max) values found for the investigated properties and strength classes $(S C)$ associated to the wood species.

Table 1. Results of physical and mechanical properties of the three investigate wood species

\begin{tabular}{cccc}
\hline Stat. & $\begin{array}{c}\text { Canafistula } \\
\boldsymbol{\rho}_{12}\left(\mathbf{g} / \mathbf{c m}^{3}\right)\end{array}$ & $\begin{array}{c}\text { Angelim Araroba } \\
\boldsymbol{\rho}_{12}\left(\mathbf{g} / \mathbf{c m}^{3}\right)\end{array}$ & $\begin{array}{c}\text { Castelo } \\
\boldsymbol{\rho}_{12}\left(\mathbf{g} / \mathbf{c m}^{3}\right)\end{array}$ \\
\hline $\bar{X}$ & 0.86 & 0.70 & 0.77 \\
$C v$ & $8.80 \%$ & $8.76 \%$ & $7.10 \%$ \\
Min & 0.74 & 0.61 & 0.69 \\
Max & 0.95 & 0.81 & 0.88 \\
\hline Stat. & $\boldsymbol{f}_{c 0}(\mathbf{M P a})$ & $\boldsymbol{f}_{c 0}(\mathbf{M P a})$ & $\boldsymbol{f}_{c 0}(\mathbf{M P a})$ \\
\hline $\bar{X}$ & 51.96 & 50.73 & 54.80 \\
$C v$ & $18.88 \%$ & $12.37 \%$ & $5.12 \%$ \\
Min & 34.90 & 40.40 & 50.30 \\
Max & 64.70 & 63.00 & 59.20 \\
\hline SC & $C 30$ & $C 40$ & $C 50$ \\
\hline
\end{tabular}

About the results it's possible point out that they showed consistent values of density and strength in compression parallel to grain with those indicated in Brazilian Code [6] for the respective strength classes. It notes that, besides the means of strength were close, the characteristic values of this property impose categorize them in different classes.

The C50 strength class was inserted due the access of authors to the draft of the new text of Brazilian Code, which was based on work of Sales and Rocco Lahr [15].

Figure 3 illustrates the variation of mean values of densities and strength in compression parallel to grain. Can (C30), Aarab (C40) and Cast (C50) represent wood species Canafístula, Angelim Araroba and Castle, respectively, and their strength classes.

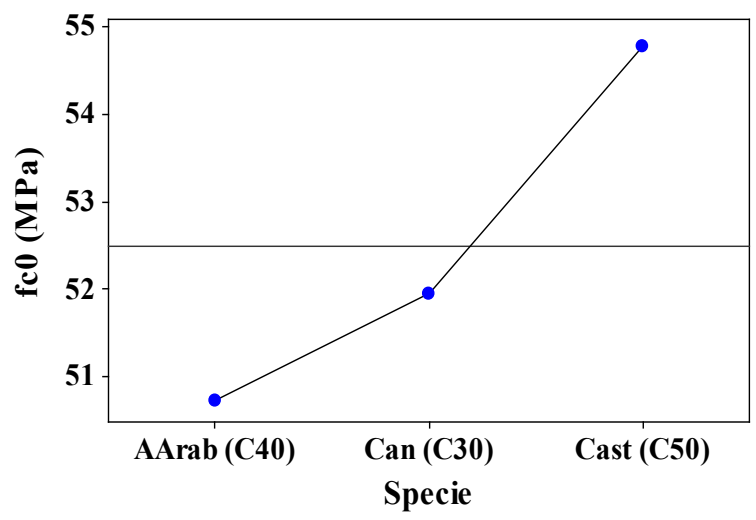

(a)

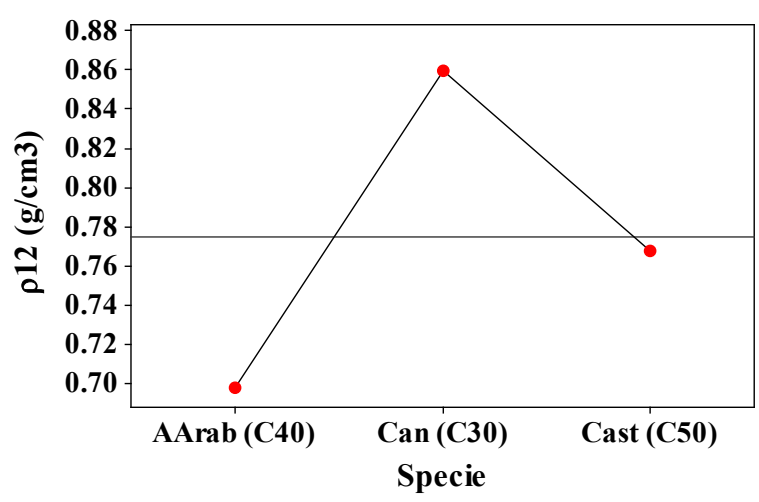

(b)

Figure 3. Variations of mean values of density (a) and strength in compression parallel to grain (b)

Table 2 shows results of the regression models, considering species alone and together. The three P-values underlined are referred to the best models for each case.

From Table 2, only the settings with Angelim araroba were not significant (P-value $>0.05)$, being significant the remaining (P-value $<0.05)$. According to IPT [16], Angelim araroba features in its anatomical features, high percentage of parenchyma cells, mostly in oblique irregular confluent arrangements. This situation favors the increased dispersion of strength in compression parallel grain and contributes to 
reduce dependence of the aforementioned mechanical properties and density.

Table 2. Estimating strength in compression parallel to grain by density $\left[f_{c 0}=f\left(\rho_{12}\right)\right]$

\begin{tabular}{|c|c|c|c|c|c|}
\hline \multirow{6}{*}{ Can } & Models & P-value & $\mathbf{a}$ & b & $R^{2}$ \\
\hline & Lin & 0.014 & -24.7706 & 89.3651 & $47.33 \%$ \\
\hline & Exp & 0.013 & 10.5838 & 1.8322 & $47.34 \%$ \\
\hline & $\log$ & 0.011 & 63.8877 & 76.4207 & $48.52 \%$ \\
\hline & Geo & 0.010 & 65.1795 & 1.5674 & $\underline{48.57 \%}$ \\
\hline & Models & P-value & a & b & $R^{2}$ \\
\hline \multirow{4}{*}{ AArab } & Lin & 0.215 & 22.9945 & 39.7928 & $14.89 \%$ \\
\hline & Exp & 0.237 & 29.8231 & 0.7521 & $13.68 \%$ \\
\hline & $\log$ & 0.222 & 60.9015 & 27.9142 & $14.45 \%$ \\
\hline & Geo & 0.245 & 61.0402 & 0.5271 & $13.25 \%$ \\
\hline \multirow{6}{*}{ Cast } & Models & P-value & $\mathbf{a}$ & b & $R^{2}$ \\
\hline & Lin & 0.008 & 26.7211 & 36.6284 & $52.32 \%$ \\
\hline & Exp & 0.007 & 32.7349 & 0.6706 & $52.44 \%$ \\
\hline & $\log$ & 0.007 & 62.4685 & 28.6092 & $52.59 \%$ \\
\hline & Geo & 0.007 & 62.9974 & 0.5244 & $\underline{52.84 \%}$ \\
\hline & Models & P-value & $\mathbf{a}$ & b & $R^{2}$ \\
\hline \multirow{4}{*}{ Group } & Lin & 0.010 & 27.8215 & 31.9149 & $17.88 \%$ \\
\hline & Exp & 0.019 & 32.8394 & 0.5949 & $15.15 \%$ \\
\hline & $\log$ & 0.011 & 59.0183 & 24.6984 & $17.58 \%$ \\
\hline & Geo & 0.020 & 58.7351 & 0.4600 & $14.87 \%$ \\
\hline
\end{tabular}

For Canafístula, the best fit was obtained with the geometric model, which provided $48.57 \%$ for the coefficient of determination $\left(\mathrm{R}^{2}\right)$.

Geometric model also provided the best settings for Castelo, showing coefficient of determination coefficient $52.84 \%$.

For woods considered in a single group, the best adjustment obtained was linear, although displaying a determination coefficient of only $17.88 \%$. This showed that, in some cases, it is not possible consider the density as a good estimator of strength in compression parallel to grain. Anatomical features can explain this aspect. Figure 4 illustrates the best models for each wood species and for the group containing the three here studied.

Pearson's correlation coefficient (r) obtained for the group involving the three wood species, was 0.423 , and the value of the Pearson correlation coefficient obtained from 80,000 simulations, via bootstrap sampling technique, was 0.261 , with confidence interval (CI) $0.18 \leq \mathrm{IC} \leq 0.65$. The great difference in the results obtained for Pearson coefficient (difference between the extreme values of CI), emphasize also the possibility of finding " $r$ " values even lower than that obtained from experimental data (0.261). It strengthened idea that there are cases in which it is not possible to estimate strength in compression parallel to grain based on density.

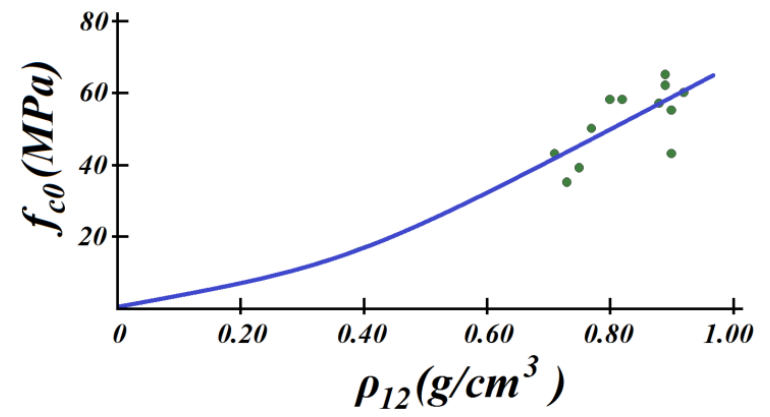

(a)

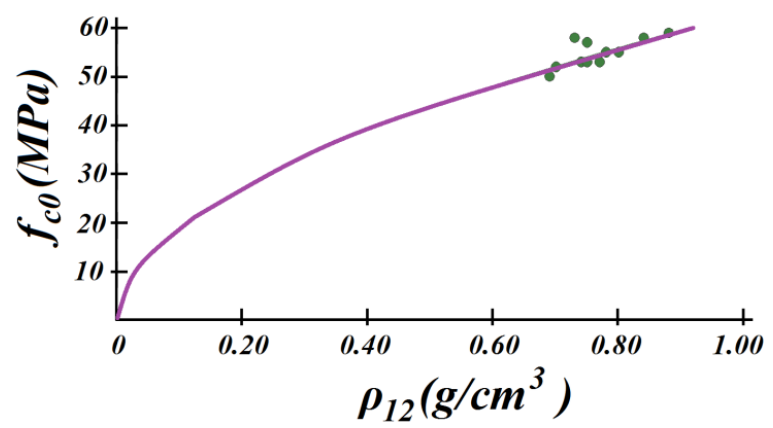

(b)

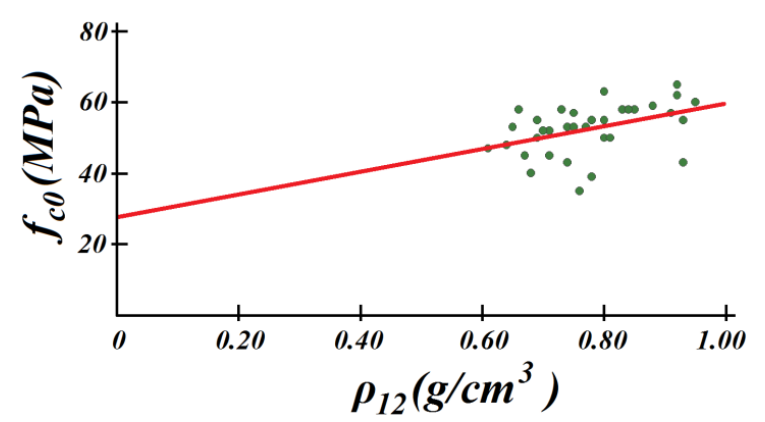

(c)

Figure 4. Best fits - Canafístula [Geo] (a), Castelo [Geo] (b) and all the species [Lin] (c)

\section{Conclusions}

Results of this study allow us to conclude that:

- For Canafístula, the best fit to relate $f_{c 0}$ and $\rho_{I 2}$ was obtained with the geometric model, which provided $48.57 \%$ for the coefficient of determination;

- For Angelim araroba no correlation was observed between values of the properties investigated, once $\mathrm{P}$-value was superior to the significance level;

- For Castelo, the best fit to relate $f_{c 0}$ and $\rho_{12}$ was also obtained with the geometric model, which provided $52.84 \%$ for the coefficient of determination;

- For the group, the highest coefficient of determination was $17.88 \%$ with the linear model.

The results show not be fully possible to estimate resistance in compression parallel to the fibers by the density 
of the wood species here investigated. However, it was also showed that due to the study of the confidence interval of the Pearson correlation coefficient by simulation, in many cases this parameter can reach appreciable values to perform proper estimates of the properties studied.

\section{REFERENCES}

[1] Almeida, T. H.; Almeida, D. H.; Marcolin, L. A.; Gonçalves, D.; Christoforo, A. L.; Lahr, F. A. R. Correlation between dry density and volumetric shrinkage coefficient of three Brazilian tropical Wood species, International Journal of Materials Engineering, 5 (2015) 1-4.

[2] Christoforo, A. L.; Almeida, T. H.; Almeida, D. H.; Santos, J. C.; Panzera, T. H.; Lahr, F. A. R. (2016). Shrinkage for some wood species estimated by density. International Journal of Materials Engineering, v. 6, p. 23-27.

[3] Calil Junior, C; Molina, J. C. Emerging Timber Bridge Program to São Paulo State: A Five-Year Report. Journal of Civil Engineering and Architecture, v. 5, p. 459-464, 2011.

[4] Almeida, D. H.; Chahud, E.; Ferro, F. S.; Poleto, S. F. S.; Almeida, T. H.; Christoforo, A. L.; Lahr, F. A. R. Physical and mechanical properties of Dipteryx odorata (Aublet) Willd, Advanced Materials Research, 1025-1026 (2014) 46-49.

[5] Dias, F. M.; Lahr, F. A. R. Strength and stiffness properties of wood esteemed trough the specific gravity, Scientia Forestalis, 65 (2004) 102-113.

[6] ABNT NBR 7190:1997. Design of structure of timber. Rio de Janeiro, 1997.

[7] Almeida, D. H.; Scaliante, R. M.; Christoforo, A. L.; Varanda, L. D.; Lahr, F. A. R.; Dias, A. A.; Calil Junior, C. Tenacidade da madeira como função da densidade aparente, Revista Árvore, 38 (2014) 203-207.
[8] Calil Junior, C.; Lahr, F. A. R.; Dias, A. A. (2003). Dimensionamento de elementos estruturais de madeira. Barueri: Manole.

[9] Pfeil, W; M. Pfeil. (2003). Estruturas de madeira, LTC. 6a edição.

[10] Calil Junior, C., Molina, J. C. Manual de projeto e construção de passarelas de estruturas de madeira. São Paulo: PINI, 2011.

[11] Almeida, D. H.; Molina, J. C.; Almeida, T. H.; Calil Junior, C. Analysis of strength and stiffness of wood from reforestation in compression loads, Proceedings of XIII Brazilian Meeting of Timber and Wood Structures, Vitória, Brazil, 2012.

[12] Kollmann, F.; Côté, W. A. (1968). Principles of wood science and technology. Germany, Springer Verlag, 592p.

[13] Bodig, J.; Jayne, B. A. (1982). Mechanics of wood and wood composites. New York, Van Nostrand Reinhold Company, $712 \mathrm{p}$.

[14] Armstrong, J. P. et al. The effect of specific gravity on several mechanical properties of some world woods. Wood science and technology, v.18, p. 137-136, 1984.

[15] Sales, A.; Rocco Lahr, F. A. Strength and Stiffness Classes of Brazilian Timbers: the New Brazilian Code for Design of Timber Structures. International Journal of Civil \& Environmental Engineering, v. 14, p. 1-5, 2014.

[16] Mainieri C. Manual de identificação das principais madeiras comerciais Brasileiras. São Paulo: IPT; 1983.

[17] Instituto Brasileiro de Desenvolvimento Florestal/ Laboratório de Produtos Florestais (IBDF/LPF). 1988. Madeiras da Amazônia, características e utilização; Estação experimental de Curuá-Una. Brasília. 236 pp.

[18] Instituto de Pesquisas Tecnológicas do Estado de São Paulo (1956). Métodos de Ensaio adotados no IPT para o estudo de madeiras Nacionais, Boletim 31, São Paulo, Brasil, 62p. 